\title{
Annona muricata, a new host record for Alternaria alternata causing leaf spots in Uttar Pradesh, India
}

\author{
Kumar $\mathbf{S}^{1^{*}}$ and Singh $\mathbf{R}^{2}$
}

\begin{abstract}
${ }^{1}$ Herbarium Division, Birbal Sahni Institute of Palaeobotany, Lucknow- 226 007, Uttar Pradesh, India.
${ }^{2}$ Department of Botany, School of Biological Sciences, Dr. Harisingh Gour Central University, Sagar- 470003 , Madhya Pradesh, India.
\end{abstract}

Kumar S, Singh R 2015 - Annona muricata, a new host record for Alternaria alternata causing leaf spots in Uttar Pradesh, India. Plant Pathology \& Quarantine 5(2), 44-47, Doi 10.5943/ppq/5/2/2

\begin{abstract}
A severe leaf spot disease was observed on Annona muricata for the first time in Lucknow, Uttar Pradesh Province, India during September 2012. The pathogen was identified as Alternaria alternata based on morphological characteristics. This is the first time that A. alternata has been recorded as a pathogen on Annona muricata.
\end{abstract}

Key words - Alternaria alternata - Annona muricata - foliar diseases - new host record

\section{Introduction}

Annona muricata L. is an important medicinal plant of family Annonaceae, commonly known as prickly custard apple or soursop. The fruit is edible and called soursop due to its slightly acidic taste when ripe at maturity. This plant probably originated in the West Indies and in northern South America. Wild and cultivated species are found from sea-level to an altitude of 1,150 m throughout the West Indies and from southern Mexico to Peru and Argentina.

During routine surveys for the detection of foliar disease in garden plants of Birbal Sahni Institute of Palaeobotany (BSIP), Lucknow during 2012-2013, living leaves of Annona muricata exhibiting leaf spots were collected. The infection started from July-August as small, circular to sub-circular spots on old leaves and the spots continuously increased in size during SeptemberNovember. Severe infection led to attack by secondary invaders during December to mid-February and caused leaves to fall. The pathogen was identified as Alternaria alternata.

\section{Materials \& Methods}

Plant material with distinct fungal symptoms were collected from BSIP Gardens, Lucknow during 2012 and taken to the laboratory for processing by standard techniques. Detailed observations of morphological characters were carried out using an Olympus CX31 light microscope. Sides were prepared by surface scrapping, and free-hand sections were cut through infected leaf samples. The fungal material was mounted in lactophenol cotton blue for microscopic examination. Observations were made using an Olympus BX-51 light microscope with an attached Syntek USB camera. Measurements were done using a micrometer. Ten conidia and conidiophores were measured for each specimen. The fungus was identified by consulting current literature pertaining to the taxonomy of Alternaria. Dried herbarium specimens were deposited in the Ajrekar Mycological Herbarium (AMH), Agharkar Research Institute, Pune, India and duplicates were 
retained in the herbarium of the Birbal Sahni Institute of Palaeobotany (BSIP), Lucknow for future reference.

The distinct diseased leaves were cut into small fragments, surface sterilized in $1 \%$ sodium hypochlorite for 2 minutes, washed three times in sterile distilled water, and plated on potato dextrose agar (PDA), and then incubated at $25^{\circ} \mathrm{C}$ for $5-7$ days under a $12 \mathrm{~h}$ light/12 $\mathrm{h}$ dark condition. Hyphal tips from the margin of each developing colony were sub-cultured on PDA.

For determination of pathogenicity, inoculations were performed on detached, surface sterilized, healthy leaves following the method of Belisario et al. (1999). Ten leaves per isolate were used and a $5 \mu \mathrm{l}$ drop of conidial suspension containing $1 \times 10^{5} \mathrm{CFU} / \mathrm{ml}$ was placed on each leaf. The leaves were incubated in a growth chamber with $90 \%$ relative humidity and a $12 \mathrm{~h}$ photoperiod.

\section{Results}

Since 2012, during the rainy season (July to September), foliar symptoms were regularly observed on Annona muricata in BSIP Campus, Lucknow of Uttar Pradesh Province, India (Fig 1). The disease first appeared in mid-July, was widespread from the end of August through to October.

On the basis of symptomatology, fungus morphological characteristics and pathogenicity, the pathogen was identified as Alternaria alternata (Fr.) Keissler (Fig 2). Fungal colonies on PDA were initially white, becoming olivaceous, and turning brown with age. In nature and on PDA the fungus showed the following characteristics: Infection spots amphigenous, circular to irregular, brown, up to $5 \mathrm{~mm}$ in diam. Colonies amphiphyllous, effuse, brown. Stromata present, $15 \mu \mathrm{m}$ in diam. Conidiophores 2-7 in a fascicle, straight to flexuous, cylindrical, unbranched, thick-walled, smooth, 1-3 septate, brown, 10-53 × 3-5 $\mu \mathrm{m}$. Conidiogenous cells integrated, terminal, polytretic, scars thickened. Conidia simple, solitary to catenate, dry, obclavate or ellipsoidal to ovoid, rostrum present, with 2-4 transverse septa and 2-3 oblique septa, brown, base obtuse, $20-50 \times 10-20 \mu \mathrm{m}$, hilum thickened.

Material examined - India, Uttar Pradesh, Lucknow, BSIP Campus, on living leaves of Annona muricata (Annonaceae), 2 September 2012, coll. Shambhu Kumar, AMH-9515, BSIPMH029.

After 5-7 days, leaf spots similar to the original symptoms developed on all inoculated detached leaves and the pathogen, A. alternata, was consistently re-isolated from symptomatic tissue, thus fulfilling Koch's postulates. The control leaves, inoculated with sterile distilled water, remained symptomless.

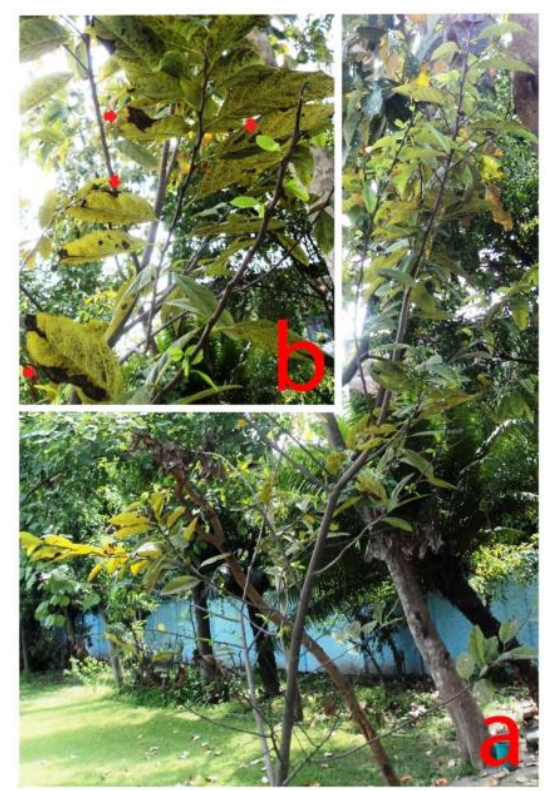

Fig 1 - Annona muricata. a Host plant habit. b Symptoms on leaves (arrowed). 


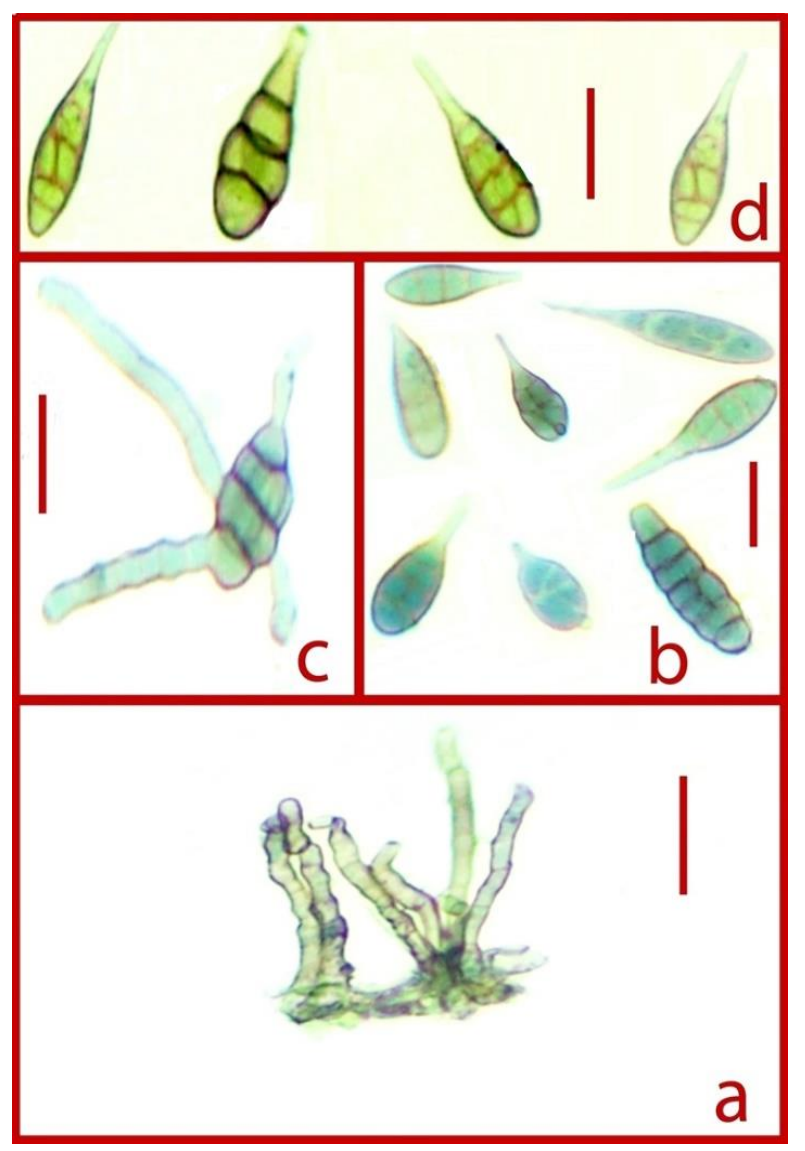

Fig 2 - Alternaria alternata (AMH - 9515). a Conidiophores. b, d Simple conidia. c Germinating conidium - Bars: $\mathrm{a}-\mathrm{d}=10 \mu \mathrm{m}$.

\section{Discussion}

Alternaria alternata (Ellis 1971, Simmons 2007) is an ubiquitous fungal pathogen reported globally on different hosts. However, A. alternata has not been reported to cause leaf spot disease on Annona muricata either from India (Bilgrami et al. 1979, 1981, 1991, Butler \& Bisby 1954, Jamaluddin et al. 2004, Sarbhoy et al. 1975, 1986, 1996) or elsewhere in the world (Farr \& Rossman 2015, Mycobank 2015, Index Fungorum 2015). The present leaf spot disease is very significant and may warrant control measures. Leaf spot disease of Annona muricata caused by A. alternata is the first report from India as well as for science.

\section{Acknowledgements}

The authors are grateful to the Director, Birbal Sahni Institute of Palaeobotany, for providing facilities during the present work. We are much appreciated to anonymous reviewer for useful suggestions. Thanks are also due to the Curator of Ajrekar Mycological Herbarium (AMH), Agharkar Research Institute, Pune, India for depositing specimens and providing accession number. Science and Engineering Research Board (SERB), Department of Science and Technology (DST), Government of India, New Delhi is acknowledged for financial assistance as Fast Track Young Scientist Start-Up Project Grant (SB/YS/LS-288/2013).

\section{References}

Belisario A, Forti E, Corazza L, Van Kesteren HA. 1999 - First report of Alternaria alternata causing leaf spot on English walnut. Plant Disease 83(7), 696.

Bilgrami KS, Jamaluddin, Rizwi MA. 1979 - Fungi of India I. List and references. Today's and Tomorrow's Printer's and Publisher's, New Delhi. 467 p. 
Bilgrami KS, Jamaluddin, Rizwi MA. 1981- Fungi of India II. Host index and addenda. Today's and Tomorrow's Printer's and Publisher's, New Delhi. 128 p.

Bilgrami KS, Jamaluddin, Rizwi MA. 1991 - Fungi of India. List and references. Today's and Tomorrow's Printer's and Publisher's, New Delhi. 798 p.

Butler EJ, Bisby GR. 1954 - Fungi of India (Revised by R.S.Vasudeva). Indian Agricultural Research Institute, New Delhi. 552 p.

Ellis MB. 1971 - Dematiaceous Hyphomycetes. Commonwealth Mycological Institute, Kew, Surrey, England. 608 p.

Farr DF, Rossman AY. 2015 - Fungal databases, systematic mycology and microbiology laboratory, ARS, USDA. Retrieved April 30, 2015, http://nt.ars-grin.gov/fungaldatabases/

Index Fungorum (www.indexfungorum.org; accessed 30 April 2015).

Jamaluddin, Goswami MG, Ojha BM. 2004 - Fungi of India 1989-2001, Scientific Publishers, Jodhpur, India. 326 p.

MycoBank (www.MycoBank.org; accessed 30 April 2015).

Sarbhoy AK, Lal G, Varshney JL. 1975 - Fungi of India (revised) 1967-1971. Navyug Traders Bookseller \& Publishers, New Delhi. 148 p.

Sarbhoy AK, Agarwal DK, Varshney JL. 1986 - Fungi of India (1977-1981). Associated Publishing Company, New Delhi. 274 p.

Sarbhoy AK, Agarwal DK, Varshney JL. 1996 - Fungi of India (1982-1992). CBS Publishers and Distributors, New Delhi. 350 p.

Simmons EG. 2007 - Alternaria: An identification manual. The American Phytopathological Society, St. Paul, MN. 